\title{
Konstruksi Messianisme Jamaah An-Nadzir Di Kabupaten Gowa Sulawesi Selatan
}

\author{
Imran \\ imrannefsana@gmail.com \\ Gadjah Mada University of Yogyakarta
}

\begin{abstract}
This study aims to explore primary aspects of the messianistic movement of Jamaah an-Nadzir in South Sulawesi. These aspects include how the messianistic ideology of this organization is formulated and practiced, and how they distinguish the movement from other similar messianistic movements elsewhere. This study is intended more as a cultural, rather than theological, study. Therefore, it is beyond the objective of this study to support or negate certain theological claims regarding the issue in question. Messianism in this study will be, thus, viewed from the perspective of the invention of tradition to explore the extent to which the idea of an-Nadzir's messianism has come as a creation and to uncover the power-relation discourses in various constructions of messianism. Members of Jamaah an-Nadzir believe and claim that they are preparing themselves for the coming of the messiah of Islam, Imam Mahdi. However, they appear to develop a construction of messianism, which is different from those of other Islamic organizations. The Imam Mahdi concept advocated by this religious group is contextualized within an array of local stories. It is, for example, strongly connected to a prominent local figure of Kahar Muzakkar and the founding father of the organization, Kyai Samsuri Abdul Madjid.
\end{abstract}

Keywords: Religious Movement, Messianism, Construction, Invention, Knowledge Relation.

\section{الخلاصة}

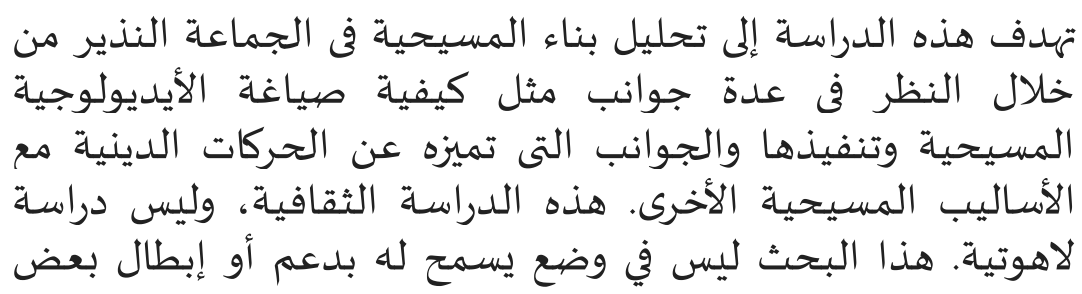




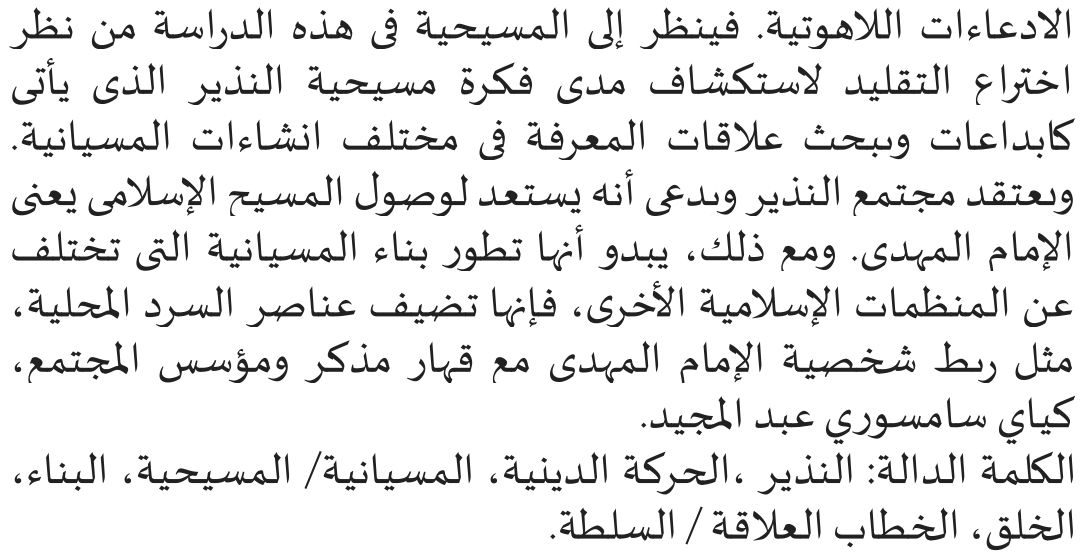

\begin{abstract}
Abstrak
Penelitian ini bertujuan untuk menganalisis konstruksi messianisme dalam Jamaah an-Nadzir dengan melihat beberapa aspek seperti bagaimana ideologi messianistik tersebut dirumuskan dan dijalankan serta aspek-aspek yang membedakannya dengan gerakan-gerakan keagamaan dengan corak messianistik lainnya. Penelitian ini merupakan sebuah penelitian kajian budaya, dan bukan kajian teologis. Penelitian ini tidak dalam posisi untuk mendukung atau menegasikan klaim teologis tertentu. Messianisme dalam penelitian ini dipandang dari perspektif invention of tradition untuk menelusuri sejauh mana gagasan messianisme an-Nadzir hadir sebagai sebuah kreasi dan menelusuri relasi kuasa pengetahuan dalam berbagai konstruksi messianisme. Komunitas an-Nadzir meyakini dan mengklaim bahwa mereka sedang mempersiapkan kedatangan sosok mesias Islam, Imam Mahdi. Uniknya, mereka menambahkan unsur narasi lokal, seperti menghubungan sosok Imam Mahdi dengan Kahar Muzakkar dan pendiri komunitas, Kyai Samsuri Abdul Madjid.
\end{abstract}

Kata kunci; Gerakan Keagamaan, Messianisme, Konstruksi, Kreasi, Relasi Wacana/Kekuasaan.

\title{
A. Pendahuluan
}

Proses liberalisasi dan globalisasi dalam berbagai bentuk yang sedang melanda seluruh penjuru dunia serta berdampak pada seluruh aspek kehidupan manusia membuat beberapa kalangan meramalkan bahwa kehidupan manusia akan terbawa pada arus kehidupan yang lebih sekular. Manusia cenderung akan meninggalkan agama atau setidak-tidaknya era ini akan ditandai dengan berkurangnya aspek religiusitas umat manusia ${ }^{1}$. Ramalan tersebut sepertinya tidak sepenuhnya tepat 
jika ditempatkan dalam konteks masyarakat Indonesia. Globalisasi ternyata tidak serta-merta membuat masyarakat Indonesia menjadi masyarakat yang lebih sekular, beberapa fenomena bahkan menunjukkan bahwa terjadi semacam penguatan aspek religuitas dan gerakan-gerakan keagamaan pada masyarakat.

Fenomena penguatan atau kebangkitan gerakan keagamaan sebenarnya bukanlah fenomena khas Indonesia. Di tempat lain fenomena yang demikian itu juga dapat dengan mudah dijumpai. Hal ini boleh jadi adalah respons terhadap modernisasi yang disikapi secara beragam oleh berbagai pihak. Bagi kaum Modernis, sekularisasi terhadap dimensi kehidupan manusia dianggap sebagai jalan menuju pencerahan umat manusia dari belenggu fenomena agama yang 'terbelakang', 'tahayyul' atau 'reaksioner'. Sebaliknya oleh kelompok yang menolak ide modernitas (termasuk oleh sebagian kelompok agama), modernisasi (sekularisasi) dianggap sebagai penyebab utama dekadensi nilai-nilai agama, baik dalam ranah masyarakat maupun dalam ranah individu. Meskipun terlihat saling bertentangan, namun relasi kedua kelompok ini sepertinya tidak sekadar dalam bentuk pengingkaran satu sama lain, tetapi juga terdapat adaptasi dan negosiasi di antara keduanya ${ }^{2}$.

Asal-usul kebangkitan agama ini bisa muncul karena dua hal menurut Peter L Berger dalam artikelnya 'The Desecularization of The World', yaitu; Pertama, modernitas cenderung memporak-porandakan kepastian-kepastian yang telah diterima secara taken for granted oleh masyarakat sepanjang zaman. Tindakan ini tidak disukai oleh penganut agama yang tidak bersikap toleran serta gerakan-gerakan keagamaan yang menghendaki kepastian tersebut dapat dipertahankan. Kedua, kenyataan bahwa pandangan sekuler tentang realitas memperoleh tempat sosial yang penting dalam kultur elit, sehingga menimbulkan kemarahan dari kalangan yang tidak ikut ambil bagian, dan kalangan yang merasa hal tersebut akan menimbulkan pengaruh buruk.

Selain fenomena penguatan keagamaan, salah satu fenomena yang menarik adalah munculnya aliran-aliran keagamaan yang lebih beragam. Hal ini disebabkan keleluasaan untuk berkumpul dan berpendapat yang sudah dapat dilakukan secara lebih terbuka oleh masyarakat setelah sekian lama dibungkam dan dikekang rezim Orde Baru pimpinan Soeharto. Namun pertumbuhan keberagaman aliran dan penafsiran yang berkaitan dengan persoalan keagamaan tersebut bukannya tanpa persoalan. Kehadiran berbagai aliran baru (sebagian bahkan telah ada sebelum reformasi) seringkali tidak dibarengi dengan kedewasaan untuk saling menerima perbedaan. Kelompok minoritas seringkali mendapatkan perlakuan yang tidak adil dan diskriminatif. Beberapa komunitas agama non-mainstream bahkan didefinisikan sebagai aliran sesat oleh komunitas dominan/ mainstream atau oleh institusi Negara. Tidak hanya itu, komunitas yang didefinisikan sesat tersebut bahkan kerap kali mendapatkan perlakuan kekerasan yang mengancam keselamatan hidup mereka. Sebut saja penyerangan, pengusiran, dan kekerasan terhadap kelompok Ahmadiyah di berbagai daerah di Indonesia atau penyerangan yang menyebabkan kerugian material dan korban jiwa terhadap komunitas Syiah di Sampang, Madura oleh kelompok tertentu dengan dalih bahwa hal itu dilakukan sebagai tindakan protektif 'terhadap keyakinan yang benar' 4 .

Terlepas dari segala macam pembelaan yang diutarakan setiap kali terjadi konflik berbau agama (baik antar kelompok seagama maupun antar agama) yang 
sering dianggap hanya merupakan rekayasa konflik dan untuk kepentingan politis tertentu, namun hal yang sepertinya sulit dipungkiri adalah bahwa benih kebencian terhadap kelompok yang 'berbeda' memang sungguh ada dan telah ditanamkan baik secara sadar maupun tidak sadar. Sebab provokasi tidak akan berhasil dengan mudah jika benih-benih kebencian tidak ada. Sebagian besar penganut agama masih tidak bisa menerima kelompok lain yang 'berbeda' dengan kelompoknya. Hal ini menunjukkan bahwa masih ada jarak antara ajaran agama yang katanya membawa spirit perdamaian dengan tindakan 'beragama's .

Fenomena lain yang muncul belakangan- walaupun sebenarnya fenomena ini bukanlah sesuatu yang benar-benar baru- adalah munculnya komunitas-komunitas agama dengan semangat messianistik. Gerakan messianistik adalah sebuah gerakan keagamaan yang merindukan datangnya juru selamat untuk menyelamatkan kehidupan manusia dan menegakkan hukum Tuhan secara menyeluruh. Dalam beberapa penelitian terdahulu, gerakan agama yang berorientasi messianistik kerap dihubungkan dengan keadaan sosial masyarakat yang carut marut (baik dari segi sosial, ekonomi politik, dan agama). Gerakan messianistik juga dalam arti tertentu kerap dianggap sarat dengan semangat revolusioner dan olehnya itu dianggap sangat berpotensi mengancam stabilitas kekuasaan pemerintah ${ }^{6}$.

Namun demikian, apakah gerakan agama yang messianistik selalu muncul sebagai respon atas ketidakjelasan kondisi sosial masyarakat? Apakah semua gerakan messianistik secara reduksionis dapat dikatakan berpretensi mengganggu kemapanan kekuasaan? Kompleksitas dalam gerakan messianistik inilah yang ingin saya coba telusuri melalui aspek-aspek gerakan messianistik yang terdapat dalam komunitas Jamaah an-Nadzir di Kabupaten Gowa, Sulawesi Selatan.

Gerakan agama dengan corak messianisme inilah yang akan menjadi fokus penelitian ini. Rencana penelitian ini dimaksudkan untuk menelusuri seperti apa aspek-aspek gerakan messianistik yang terdapat pada komunitas Jamaah an-Nadzir di kabupaten Gowa, Sulawesi Selatan. Penelitian ini juga dimaksudkan untuk melihat bagaimana ideologi messianistik tersebut dirumuskan dan dijalankan serta aspekaspek yang membedakannya dengan gerakan-gerakan keagamaan dengan corak messianistik lainnya. Penelitian ini juga akan menelusuri bagaimana latar belakang sosial serta interpretasi jamaah an-Nadzir terhadap kondisi sosial saat ini, hal ini penting karena biasanya gerakan messianistik menginterpretasikan kondisi sosial saat ini sebagai sesuatu yang dekaden khususnya dari segi moralitas.

Penelitian ini tidak dimaksudkan untuk mengafirmasi ataupun membenarkan klaim tertentu dari berbagai pihak tentang siapa sosok Imam Mahdi. Penelitian ini juga tidak akan membahas tentang otentitas dalil-dalil (hadis) yang digunakan oleh berbagai kelompok Islam untuk mereprepsentasikan pemahaman mereka tentang Imam Mahdi. Penelitian ini bukanlah penelitian kajian teologi melainkan penelitian kajian budaya. Messianisme dalam hal ini dipandang sebagai sebuah fenomena budaya yang terdapat pada masyarakat -dalam hal ini adalah Jamaah an-Nadzir-. Penelitian ini berupaya menelusuri bagaimana konsep dibangun, hal-hal yang memengaruhinya, serta bagaimana konsep tersebut dipraktikkan.

Penelitian ini adalah penelitian lapangan (field research) untuk menelusri konsep-konsep messianistis dan pengamalan anggota jamaah dalam kehidupan sehari- 
hari. Metode yang digunakan dalam pendekatan ini adalah indepth interview (wawancara mendalam), dan observasi lapangan. Penelitian ini akan menggunakan lived experience and discourse. Pendekatan ini dipilih karena aspek lived experience akan memfokuskan penelitian ini pada pengalaman subjek/pelaku dalam kaitannya dengan kekuatan diskursus yang bekerja di lingkungan sosialnya. Sedangkan diskursus digunakan untuk melihat kompleksitas kontruksi konsep messianisme.

Gerakan messianistik sendiri bukanlah hal baru bagi masyarakat Indonesia. Berbagai macam gerakan messianistik telah dikenal oleh masyarakat nusantara bahkan ketika Indonesia sebagai Negara belum ada. Masyarakat Jawa misalnya telah mengenal konsep Ratu Adil yang biasanya dihubungkan dengan ramalan dari Prabu Jayabaya tentang keadaan masa depan masyarakat Jawa ${ }^{7}$. Masyarakat di Sulawesi Selatan yang menjadi lokasi penelitian ini juga telah mengenal konsep messianisme sejak lama lewat konsep To Manurung. Konsep tentang To Manurung ini sendiri sebenarnya tidak serta merta mengandung arti messianis, namun dalam perkembangannya konsep To Manurung sangat kental dengan unsur-unsur messianistik.

Konsep To Manurung sendiri merupakan konsep yang erat kaitannya dengan sejarah terbentuknya kerajaan-kerajaan besar di Sulawesi Selatan (Kerajaan Gowa, Bone, Soppeng). Kedatangan To Manurung di Sulawesi Selatan digambarkan oleh lontara ${ }^{8}$ sebagai sesuatu yang dihajatkan, antara lain untuk mengakhiri keadaan yang sedang kacau balau ${ }^{9}$. Pengharapan tentang datangnya to-manurung seringkali muncul apabila masyarakat berhadapan dengan ketidakpastian sosial yang berlangsung secara terus menerus. Konsep ataupun gerakan yang bersifat messianistik seperti ini di Sulawesi Selatan mengalami metafora setelah perjumpaan antara unsur kepercayaan lokal dengan unsur eskatologi Islam. Hal yang sama sepertinya juga berlaku dalam konsep Ratu Adil masyarakat Jawa, bahkan dalam arti tertentu konsep tentang Ratu adil di Jawa sedikit lebih kompleks karena mempertemukan unsur kepercayaan/kebudayaan lokal yang bertemu dengan konsep Hindu-Budha dan konsep eskatologi Islam.

\section{B. Kajian Teoretis}

Penelitian ini akan menjadikan konsep 'invention of tradition' sebagai sudut pandang utama penelitian. Konsep invention of tradition bukanlah sebuah konsep yang sangat 'teoritis' jika dibandingkan dengan teori-teori besar seperti psikoanalisa, poskolonialisme dan sebagainya. Konsep ini hanya seperti sebuah batasan dan fokus penelitian. Eric Hobsbawm menjelaskan konsep 'invention of tradition' sebagai berikut;

"Invented tradition" is taken to mean a set of practices, normally governed by overtly or tacitly accepted rules and of a ritual or symbolic nature, which seek to inculcate certain values and norms of behaviour by repetition, which automatically implies continuity with the past. In fact, where possible, they normally attempt to establish continuity with a suitable historic past. ${ }^{10}$

Penjelasan Hobsbawm tersebut menunjukkan bahwa 'Invented Tradition' yang terjadi di berbagai tempat bukanlah praktek natural, melainkan sebuah praktek yang memang sengaja disusun sedemikian rupa untuk maksud -kebanyakan sangat 
bersifat politis- dalam kurun waktu tertentu. Menariknya, 'penciptaan tradisi' tersebut senantiasa mengandaikan keterhubungan atau kontinuitas dengan masa lalu. Artinya, masa lalu berusaha dimaknai ulang pada masa sekarang. Masa lalu dimaknai kembali untuk menyusun kondisi yang diekspektasikan pada masa sekarang dan masa depan. Pemaknaan kembali ini- yang tentunya sekali lagi sarat nuansa politis- sangat memungkinkan terjadinya pertarungan wacana dalam rangka merebut atau memapankan makna tertentu.

Kerangka invention of tradition yang digunakan dalam penelitian ini akan berusaha dilengkapi dengan konsep wacana Foucauldian untuk melihat kompleksitas dari data yang diperoleh secara lebih mendalam. Konsep wacana Foucauldian dimaksudkan untuk melihat secara kritis bagaimana wacana messianisme dibentuk dan relasi-relasi kekuasaan-pengetahuan yang menyertainya. Wacana dan kekuasaan yang saling mengandaikan tersebut berusaha mendisplinkan orang-orang yang terlibat dalam dinamika wacana/kekuasaan tersebut ${ }^{11}$. Bagaimanapun messianisme adalah sebuah medan wacana yang sarat dengan kontestasi, gerakan keagamaan dengan corak messianisme biasanya saling menegasikan demi mengafirmasi klaim kebenaran konstruksi wacana mereka. Hal ini tidak bisa dilepaskan dari konsep messianisme pada sebuah konsep teologis tertentu biasanya multi interpretatif dan tidak menjelaskan secara pasti dan detail siapa dan bagaimana sang messias dan komunitasnya akan muncul.

Kebanyakan penelitian Foucault berkaitan dengan sejarah seperti penelitiannya terhadap bagaimana konstruksi wacana seksualitas dan sejarah kelahiran penjara, namun Foucault tidak hanya memahami sejarah semata sebagai sebuah peristiwa kronologis melainkan peristiwa-peristiwa tersebut difokuskan pada bagaiamana relasi rezim kekuasaan-pengetahuan-kenikmatan yang menopang wacana/peristiwa sejarah tersebut ${ }^{12}$. Penelitian Foucault tentang sejarah seksualitas bukan merupakan sejarah representasi melainkan bagaimana seksualitas berusaha diatur sedemikian rupa untuk menghasilkan kepatuhan terhadap wacana tertentu.

Pemikiran Foucault memang tidak bisa dilepaskan dari persoalan relasi kekuasaan. Kalau orang biasanya berbicara tentang kekuasaan dan Negara, sekarang tentang kekuasaan dan subjek. Berlawanan dengan pandangan Marxis, Foucault menentang paham kekuasaan dari atas oleh pusat kekuasaan Negara. Tekanan pada hubungan kekuasaan tidak mengacu pada sistem umum dominasi oleh suatu kelompok terhadap kelompok yang lain. Melainkan beragamnya hubungan kekuasaan. Syarat-syarat kemungkinan pemahaman kekuasaan tidak terpusat pada satu titik atau sumber otoritas ${ }^{13}$. Menurut Foucault, kita seharusnya bersikap nominalis dalam memandang kekuasaan. kekuasaan bukanlah lembaga, kekuasaan bukan pula sebuah struktur, bukan semacam daya yang terdapat pada beberapa orang. Kekuasaan adalah nama yang diberikan kepada suatu situasi strategis yang rumit dalam masyarakat tertentu ${ }^{14}$.

Kekuasaan yang di maksudkan Foucault bukan Kekuasaan dengan huruf besar sebagai himpunan lembaga dan perangkat yang menjamin kepatuhan warga negara ${ }^{15}$. Biasanya kekuasaan disamakan dengan dengan milik. Kuasa dianggap sebagai sesuatu yang dapat diperoleh, disimpan, dibagi, ditambah, atau dikurangi, tetapi dalam pandangan Foucault, kekuasaan bukanlah sesuatu yang dimiliki tetapi dipraktikkan 
dalam suatu ruang lingkup di mana ada banyak posisi yang secara strategis berkaitan satu sama lain dan senatiasa mengalami pergeseran ${ }^{16}$. Menurut Foucault kekuasaan ada di mana-mana, bukan karena kekuasaan mencakupi segala hal, namun karena kekuasaan datang dari mana-mana. Dengan memahami kekuasaan sebagai sesuatu yang tersebar, maka relasi kekuasaan dapat ditemui dalam berbagai interaksi masyarakat dan kegiatan sosial seperti sekolah, rumah sakit, penjara dan sebagainya.

Pelaksanaan kekuasaan bukan pertama-tama melalui kekerasan atau masalah persetujuan (Hobbes, Locke), tetapi seluruh struktur tindakan yang menekan dan mendorong tindakan-tindakan lain melalui rangsangan, rayuan, atau melalui paksaan dan larangan. Jadi kekuasaan pertama-tama bukan represi (Freud, Reich) atau pertarungan kekuatan ( Machiavelli, Marx) dan bukan pula fungsi dominasi suatu kelas yang didasarkan pada penguasaan atas ekonomi atau manipulasi ideologi (Marx). Foucault mengatakan kekuasaan harus dipahami pertama-tama banyak dan beragamnya hubungan-hubungan kekuatan yang melekat pada bidang hubunganhubungan tersebut dan organisasinya. Kekuasaan berarti perang bisu, yang menempatkan konflik dalam berbagai institusi sosial, dalam ketidaksetaraan ekonomi, dalam bahasa, dan bahkan dalam tubuh kita masing-masing ${ }^{17}$.

Selain mengatakan bahwa kekuasaan sesuatu yang lebih dipraktikkan daripada dimiliki dan tersebar, Foucault juga mengatakan bahwa di mana pun kekuasaan berada, selalu ada resistensi yang menyertainya ${ }^{18}$. Perlawanan tersebut tidak berada pada posisi di luar kekuasaan. Perlawanan ada karena kekuasaan itu sendiri. Berkaitan dengan penelitian ini apa yang dipraktikkan Jamaah an-Nadzir dapat dilihat sebagai sebuah bentuk resistensi terhadap wacana Islam dominan. Model Invention of Tradition dan konsep wacana Foucaldian sangat relevan digunakan dalam penelitian ini sebab wacana 'Islam dominan' merupakan sebuah bentuk konstruksi 'pengetahuan-kekuasaan, sementara apa yang dipraktikkan dan diargumentasikan oleh Jamaah an-Nadzir dapat dilihat sebagai sebuah resistensi melalui penciptaan konsep 'kekuasaan-pengetahuan' alternatif.

Foucault mengoreksi imaji negatif yang sering dilekatkan pada kekuasaan sebagai sesuatu yang dilaksanakan dengan cara-cara represif, menyensor, mengabstraksi dan menyembunyikan. Bagi Foucault, kekuasaan tidak hanya represif tetapi juga produktif. Kekuasaan memproduksi realitas, kekuasaan memproduksi ruang lingkup objek dan ritus-ritus kebenaran. Kekuasaan dalam mekanisme disiplinnya menghasilkan individu dan pengetahuan ${ }^{19}$.

Apa yang menjadi sasaran kekuasaan? menurut Foucault, sasaran kekuasaan adalah tubuh. Tubuh dimanipulasi, dilatih, dikoreksi, dibuat menjadi patuh, bertanggungjawab, menjadi terampil dan meningkat kekuatannya ${ }^{20}$. Tubuh selalu menjadi objek sasaran kuasa baik dalam arti anatomi metafisik seperti yang dibuav oleh para dokter maupun filsuf, maupun dalam arti 'teknis politis' yang mau mengatur, mengontrol atau mengoreksi segala aktivitas tubuh. Kuasa dari masa ke masa selalu menyentuh tubuh, hanya cara, ukuran, dan sasaran kontrolnya saja yang selalu berubah-ubah ${ }^{21}$.

Konsep kekuasaan tidak dapat dilepaskan dari pengetahuan. Antara pengetahuan dan kekuasaan terdapat relasi yang saling mengandaikan. Tidak ada praktik pelaksanaan kekuasaan yang tidak memunculkan pengetahuan, dan tidak ada 
pengetahuan yang di dalamnya tidak mengandung relasi kuasa ${ }^{22}$. Pengetahuan adalah cara bagaimana kekuasaan memaksakan diri kepada subjek. Foucault mendefinisikan strategi kekuasaan sebagai yang melekat pada kehendak untuk mengetahui. Melalui wacana, kehendak untuk mengetahui terumus dalam pengetahuan. Bahasa menjadi alat untuk mengartikulasikan kekuasaan pada saat kekuasaan harus mengambil bentuk pengetahuan, karena ilmuilmu terumus dalam bentuk pernyataan-pernyataan ${ }^{23}$.

Disiplin dan norma menjadi konsep kunci dalam mekanisme kekuasaan. Kekuasaan ingin mencapai tubuh yang selalu patuh. Untuk kepentingan tersebut diperlukan sebuah penerapan disiplin sistematis yang mendapatkan bentuknya melalui model penjara panoptik. Bangunan panoptikon merupakan bangunan besar, berbentuk melingkar dengan menara pengawas terdapat di tengah-tengahnya. Melalui mekanisme panoptik, pengawas dapat secara terus menerus memantau individu tanpa pernah dilihat oleh mereka yang diawasi. Model ini menciptakan dalam diri subjek perasaan senantiasa diawasi. Pada akhirnya orang menciptakan pengawas dari dalam dirinya sendiri

Agama merupakan salah satu lembaga produksi kekuasaan-pengetahuan yang dahsyat, terutama dalam masyarakat seperti Indonesia. Dia tidak bisa dilepaskan dari mekanisme dan teknik kekuasaan normatif dan disipliner. Agama mengatur individu dan masyarakat melalui penyeragaman baik perilaku, bahasa, pakaian, maupun ritus. Melalui teknik itu akan dihasilkan identitas yang memudahkan pencapaian baik dari pemeluknya, maupun ketakutan dari mereka yang tidak termasuk bagiannya ${ }^{24}$.

\section{Genealogi dan Karakteristik Jamaah An-Nadzir}

Komunitas Jamaah an-Nadzir adalah kelompok Islam minoritas yang terdapat di wilayah Kabupaten Gowa, Sulawesi Selatan. Jamaah an-Nadzir yang berasal dari berbagai daerah dan latar belakang tersebut memilih bertempat tinggal sebagai sebuah komunitas mandiri di tempat yang cukup terpencil tepatnya di tepi danau Mawang, Kabupaten Gowa, Provinsi Sulawesi Selatan sekitar 20 Kilometer dari kota Makassar. Selain di Kabupaten Gowa, Komunitas an-Nadzir memiliki jaringan di berbagai daerah di Indonesia, mulai dari Jakarta, Medan, Banjarmasin, Batam, Dumai, Batubara, Bogor, dan di berbagai daerah di Sulawesi Selatan. ${ }^{25}$

Jamaah an-Nadzir di Indonesia didirikan oleh Kyai Syamsuri Abdul Madjid pada tahun 1998 yang melakukan perjalanan dakwah ke berbagai daerah di Indonesia termasuk di Sulawesi Selatan, khususnya di Makassar dan di Luwu. Menariknya, Kyai Syamsuri Abdul Madjid oleh anggota Jamaah an-Nadzir kerap dikaitkan sebagai sosok titisan Kahar Muzakkar, tokoh pejuang gerakan DI/TII di Sulawesi Selatan. Di awal keberadaannya, Jamaah an-Nadzir ini sempat menimbulkan kecurigaan dari berbagai pihak, bahkan kepolisian dan intelejen sempat mendatangi komunitas mereka karena dicurigai melakukan praktik terorisme ataupun menyebarkan ajaran 'sesat' 26 .

Anggapan bernada miring tersebut dikarenakan Jamaah an-Nadzir memiliki kekhasan yang membedakannya atau dianggap berbeda dengan umat Muslim pada umumnya. Jamaah laki-laki An-Nadzir rata-rata berambut panjang sebahu, selain itu mereka juga mewarnai rambutnya (dengan warna dominan kuning atau merah). Para Jamaah laki-laki juga memelihara jenggot dan memanjangkannya. Ciri khas lain 
Jamaah an-Nadzir adalah pakaiannya. Mereka biasanya memakai jubah dan sorban di kepala, serta memakai celak. Sementara itu jamaah perempuan berpakaian tertutup dengan jilbab besar disertai kain penutup muka. Tata cara berpakaian dan tampilan fisik seperti ini juga mereka terapkan kepada anak-anak mereka. Selain itu para anggota jamaah yang sudah dewasa juga selalu membawa badik ${ }^{27}$ di balik celana jika mereka bepergian di sekitar wilayah kelurahan yang mereka tempati. Menariknya, kebiasaan membawa senjata tajam ini terkesan dibiarkan dan dimaklumi oleh aparat keamanan setempat dan dianggap sebagai sesuatu yang 'khas' An-Nadzir.

Tata cara berpakaian dan tampilan fisik seperti ini menurut Jamaah an-Nadzir merupakan tata cara berpakaian yang diterapkan oleh Rasulullah kepada umatnya. Mereka berpakaian seperti itu dalam rangka menjalankan sunnah Rasulullah. Argumentasi mengenai cara berpakaian mereka dapat dilihat dari petikan wawancara yang saya lakukan dengan seorang jamaah bernama Ismail yang merupakan salah satu pengikut awal Jamaah an-Nadzir.

Begini, kami di sini itu hanya berusaha menjalankan sunnah Rasulullah. Dalam menjalankan sunnah rasul itu kami di sini tidak memilih-milih mana sunnah yang ringan atau menguntungkan kami saja. Tata cara berpakaian seperti ini itu adalah sunnah nabi. Nabi itu ketika memasuki Makkah pada saat Fathul Makkah mengepang dua rambutnya dan mengecat rambutnya. Bagaimana mungkin nabi bisa mengepang rambutnya kalau rambutnya itu pendek seperti rambutmu. Yang bisa dikepang hanya rambut yang panjang.

Jamaah an-Nadzir melakukan kritik balik terhadap orang-orang yang mengkritik cara berpakaian mereka yang dianggap esensialis, puritan dan terlalu skriptualis dalam memaknai teks-teks suci dengan mengatakan bahwa umat Islam saat ini sudah jauh meninggalkan ajaran nabi dalam tata cara berpenampilan. Menurut Jamaah an-Nadzir saat ini tata cara berpakaian laki-laki dan perempuan Muslim sudah terbalik, di mana laki-laki berpenampilan tertutup sementara para perempuan malah berpakaian lebih terbuka. Fenomena yang demikian itu menurut An-Nadzir sudah bertentangan dengan ajaran Nabi Muhammad.

Kekhasan Jamaah an-Nadzir tidak hanya terletak pada penampilan fisik dan tafsiran teologi mereka tetapi juga cara hidup dan pola ekonomi mereka. Komunitas an-Nadzir berusaha mengembangkan sebuah pola ekonomi mandiri untuk menghidupi dan membiayai komunitas mereka. Komunitas ini menyadari bahwa ekonomi yang kuat dapat menjadi landasan komunitas agar tetap utuh, apalagi komunitas ini kebanyakan adalah pendatang yang meninggalkan daerah dan pekerjaan mereka sebelumnya untuk hidup sebagai sebuah komunitas. Hal ini membuat pengelolaan ekonomi sangat dibutuhkan demi kelanjutan hidup komunitas.

Hal lain yang juga menarik dari Jamaah an-Nadzir adalah keputusan mereka untuk tidak menyekolahkan anak-anak mereka di sekolah-sekolah formal baik milik pemerintah maupun swasta. Mereka hanya mengajari anak-anak mereka secara otodidak. Yang diajarkan pun terbatas pada kemampuan membaca, berhitung, dan baca tulis Al-Quran. Selain itu, sejak kecil anak-anak mereka telah diajarkan kemampuan bercocok tanam, berkebun, dan berniaga sebagai modal untuk bertahan hidup. Menurut Jamaah an-Nadzir, kurikulum sekolah-sekolah yang ada saat ini 
hanya menjauhkan anak-anak dari kehidupan agama yang 'seharusnya', lagipula menurut Jamaah an-Nadzir fase hidup yang sedang kita jalani ini adalah fase akhir zaman di mana kehidupan dunia bukan lagi prioritas, kehidupan akhiratlah yang seharusnya dikedepankan dengan menghidupkan kembali kehidupan kenabian sebagaimana yang telah dicontohkan oleh nabi Muhammad SAW di masa lalu ${ }^{28}$.

Sistem pendidikan seperti ini tidak menyediakan ijazah sebagaimana layaknya sekolah-sekolah formal. Mereka sendiri tidak memproyeksikan anak-anak mereka untuk jenjang pendidikan yang lebih tinggi. Mereka hanya mempersiapkan anak-anak mereka sebagai pelanjut dari cita-cita komunitas di masa depan. Melalui sistem pendidikan yang seperti ini, Jamaah an-Nadzir mendekonstruksi pemikiran mainstream tentang pendidikan. Mereka seakan merevisi pandangan konvensional bahwa mereka tidak akan bisa hidup "layak" tanpa bantuan sistem pendidikan formal. Jamaah an-Nadzir membuktikan bahwa sebuah komunitas dapat "melanjutkan hidup" tanpa harus terjebak dalam sistem pendidikan formal yang telah tergerus dalam logika pasar kapitalisme.

Komunitas Jamaah an-Nadzir seringkali dianggap sebagai komunitas revivalis atau fundamentalis karena cara mereka menafsirkan teks-teks suci (Al-Quran dan Hadist) yang dianggap sangat skriptualis dan tekstual. Praktik-praktik keagamaan mereka termasuk konstruksi identitas dan tampilan fisik mereka biasanya dijadikan sebagai landasan dari pelabelan revivalis mereka.

Salah satu yang membedakan Jamaah an-Nadzir dengan umat Islam kebanyakan adalah cara mereka merayakan bulan suci Ramadhan. Jamaah an-Nadzir hanya melaksanakan ibadah puasa dan meniadakan ibadah shalat tarawih di malam hari. Peniadaan ini dalam pandangan Jamaah an-Nadzir karena ditakutkan shalat tarawih akan dianggap wajib. Mereka merujuk kepada nabi yang semasa hidupnya hanya melakukan ibadah tarawih pada malam ke 23, 25, dan 27 bulan Ramadhan. Dalam pandangan an-Nadzir umat Islam sekarang ini seakan-akan menjadikan ibadah shalat tarawih sebagi sebuah kewajiban ${ }^{29}$.

Jamaah an-Nadzir juga tidak mau dikategorikan dengan label Sunni maupun Syiah, dua sekte terbesar dalam dunia Islam. Mereka menyebut komunitas mereka sebagai Ahlul Bait. Ahlul Bait dalam pengertian an-Nadzir bukanlah keluarga nabi sebagaimana yang lazim dipahami. Menurut Jamaah an-Nadzir pengertian ahlulbait itu ada dua, yang pertama, keluarga langsung nabi Muhammad yang berasal dari keturunan hasil pernikahan antara Ali bin Abi Thalib dan puteri nabi, Fatimah. Kedua, defenisi Ahlulbait (versi An-Nadzir) adalah orang-orang yang melaksanakan sunnah nabi mulai dari sunnah yang kecil hingga sunnah yang besar tanpa memilah-milih ajaran yang dianggap ringan atau hanya menguntungkan dirinya sendiri. Itu berarti ahlul bait adalah orang yang meletakkan nabi sebagai teladan dalam segala hal. Dalam proyek mengikuti nabi itu-lah, komunitas an-Nadzir memanjangkan rambut hingga sebahu, memakai jubah, tongkat sebagai upaya menghadirkan sosok nabi dalam kehidupan sehari-hari. Dengan klaim seperti ini, Jamaah an-Nadzir berusaha merivisi definisi ahlulbait yang terbatas hanya pada keturunan nabi saja. Apa yang dilakukan Jamaah an-Nadzir ini adalah sebuah usaha politik identitas untuk 
menampilkan diri sebagai komunitas yang lebih 'berislam' (sehingga tidak mungkin sesat) dengan menjadikan kehidupan nabi sebagai medan kontestasi ${ }^{30}$.

Jamaah an-Nadzir mengkonstruksi bahwa mereka merupakan komunitas pilihan yang akan mengembalikan kehidupan Islam 'sebagaimana mestinya'. Mereka meyakini bahwa komunitasnya adalah kelompok pembawa panji-panji hitam dari Timur di akhir zaman sebagaimana telah dijanjikan dalam hadist Rasulullah. Jamaah an-Nadzir berusaha melakukan redefenisi tentang makna Timur untuk mengafirmasi argumentasi bahwa merekalah komunitas dari Timur yang dijanjikan sekaligus menegasikan kelompok-kelompok lain yang juga mengklaim sebagai kelompok yang dijanjikan. Jamaah an-Nadzir meyakini bahwa timur yang dimaksud bukanlah dari jazirah Arab melainkan wilayah Nusantara atau tepatnya Kabupaten Gowa. Menurut mereka, Gowa terletak pada wilayah paling timur, jikapun ada wilayah yang lebih timur dari Gowa tetapi komunitas yang mejalankan dan menghidupkan kembali dimensi kehidupan kenabian hanya ada di tanah Gowa, yakni komunitas mereka. Kelompok panji-panji hitam diartikan sebagai komunitas yang akan menegakkan kembali hukum-hukum Islam ${ }^{31}$.

Konstruksi an-Nadzir tentang komunitas dari 'Timur' yang dijanjikan memuat unsur revivalisme terhadap masa lalu yang dianggap sebagai kehidupan ideal yang masih 'murni'. Konstruksi tersebut juga mengadung unsur messianisme yang sangat kental. Mungkin kita dapat mengatakan bahwa pola dasar yang selalu terdapat dalam gerakan-gerakan messianistis adalah adanya anggapan bahwa masa atau realitas yang mewujud saat ini merupakan realitas yang telah terdistorsi, bukan realitas 'yang seharusnya ada'. Berangkat dari anggapan demikian itu, sebuah gerakan messianistis biasanya mengidealisasikan masa-masa tertentu di masa lalu yang dikonstruksi sebagai zaman keemasan, di mana kehidupan dan moralitas masih 'agung', di mana kehidupan berlangsung dengan adil dan setara karena ditopang oleh penegakan hukum dan kepemimpinan ilahiah.

Praktik keagamaan Jamaah an-Nadzir seperti cara dan penentuan waktu shalat, puasa dan konstruksi syariat lainnya yang dianggap agak 'nyeleneh' karena cenderung berbeda dengan praktik mayoritas umat Islam di Indonesia dan diklaim an-Nadzir sebagai ajaran 'asli' Nabi Muhammad sesungguhnya bukanlah sesuatu yang sepenuhnya baru atau hasil ciptaan dan kreasi Jamaah an-Nadzir sendiri. Kebanyakan praktik ibadah an-Nadzir -seperti tata cara shalat dan puasa- memiliki kemiripan dengan konstruksi teologi Syiah, meski Jamaah an-Nadzir tidak mau diklasifikasikan sebagai sempalan salah satu dari dua sekte besar Islam, Sunni dan Syiah. An-Nadzir menyebut diri mereka sebagai ahlubait dalam arti kelompok yang secara konsisten mengamalkan ajaran nabi Muhammad yang 'benar'.

\section{Messianisme Sebagai Medan Kontestasi}

Membicarakan Jamaah an-Nadzir sepertinya tidak akan terasa lengkap tanpa menyinggung persoalan konstruksi messianisme mereka. Harapan messianistislah yang menyatukan anggota-anggota Jamaah an-Nadzir dari berbagai latar belakang pendidikan, suku, dan profesi untuk kemudian berkumpul dan membuat sebuah komunitas mandiri di Mawang, Kabupaten Gowa. Pembentukan komunitas tersebut 
mereka anggap adalah tonggak awal untuk membuat jalan dan harapan-harapan messianistik mereka menjadi mungkin.

Messianisme adalah gagasan bahwa di akhir zaman, akan muncul seorang pemimpin- spritual dan politik- yang akan mengakhiri penderitaan panjang sebagian besar umat manusia dan membawa kehidupan manusia menuju masa paling gemilang dalam sejarah peradaban manusia, pemimpin tersebut akan memenuhi dunia dengan kesejahterahaan dan keadilan serta memusnahkan kezaliman dan penindasan di seluruh penjuru dunia. Gagasan atau pengharapan terhadap sosok messianis merupakan hal yang telah lama ada. Konsep tentang messianisme adalah konsep universal yang dapat ditemui pada hampir seluruh agama-agama besar dunia, khususnya pada agama-agama samawi -Yahudi, Kristen, Islam. Gagasan messianistik juga terdapat dalam agama Hindu, Buddha, dan Zoroaster.

Gagasan messianisme pada setiap agama berbeda-beda dan menunjukkan kekhasannya masing-masing. Orang Yahudi meyakini bahwa mereka sedang menunggu messias mereka yang belum datang, berbeda dengan Umat Kristen yang sedang menunggu kedatangan kedua Sang $\mathrm{Messiah}^{32}$. Umat Hindu menunggu kedatangan 'Krishna Kedua', penganut agama Buddha menantikan kedatangan tokoh yang serupa dengan Mahatma Gautama, Kaum Sikh mengharapkan kedatangan seorang Guru lagi, sementara Umat Islam menanti kebangkitan tokoh messianik mereka, Imam Mahdi. Pengharapan akan seorang pembebas -meskipun dalam konstruksi yang berbeda- menunjukkan bahwa gagasan messianisme adalah sesuatu yang umum diyakini dalam agama-agama dunia.

Sosok messianistik dalam teologi Islam adalah seseorang yang dikenal dengan nama al-Mahdi al-Muntadzar. Sejak kapan kepercayaan terhadap Imam Mahdi muncul dan menjadi merata di lingkungan Islam? Menjawab pertanyaan tersebut, Ibrahim Amini menulis bahwa terdapat perselisihan tentang asal-usul kepercayaan terhadap Imam Mahdi. Ada yang menyatakan bahwa ide tentang Imam Mahdi baru muncul sekitar paruh kedua abad pertama hijriah (abad $7 \mathrm{M}$ ), masa-masa di mana Umat Islam disibukkan dengan perselisihan internal. Namun demikian, sebagian besar Umat Islam meyakini bahwa gagasan tentang Imam Mahdi telah ada sejak zaman Nabi dimana Nabi Muhammad menyampaikan ihwal tentang kedatangan al-Mahdi lebih dari sekali ${ }^{33}$. Meskipun gagasan tentang Imam Mahdi adalah perkara yang familiar bagi Umat Islam, namun interpretasi tentang siapa sosok Mahdi begitu beragam. Sepanjang perjalanan sejarah Islam, telah banyak orang atau kelompok yang mengklaim diri atau pemimpin mereka sebagai sosok Mahdi yang dijanjikan.

Di Indonesia, juga terdapat berbagai gagasan messianistik yang tersebar di berbagai wilayah nusantara. Konsep-konsep messianik di Indonesia begitu beragam karena budaya masyarakat Indonesia yang memang tidak tunggal. Konsep-konsep tersebut juga tidak bisa dilepaskan dari pengaruh agama. Agama memang nampaknya seringkali menggunakan narasi kebudayaan lokal untuk dinarasikan ulang agar sesuai dengam konsep agamanya meski tetap mengakomodasi kekhasan narasi lokalnya.

Gagasan messianistik di Indonesia salah satunya dapat kita temui pada masyarakat Jawa. Berbagai ramalan tentang masa depan tanah Jawa -pasca kemerdekaan ramalan tersebut seringkali digunakan untuk meramalkan masa depan Indonesia- dan janji akan datangnya sosok pemimpin messianik dapat dengan mudah 
ditemui dalam narasi-narasi lokal Jawa. Konsep messianistik orang Jawa biasanya dikaitkan dengan ramala-ramalan Prabu Jayabaya dan penyair futurustik Jawa, Ranggowarsito yang hidup di Kasunanan Surakarta pada penghujung abad ke 19 (1802-1873).

Messianisme tidak bisa dipandang sinis sebagai hanya suatu spekulasi tentang kejadian-kejadian di masa depan, tetapi juga merupakan sebuah kekuatan yang mendorong pada tindakan-tindakan untuk merubah situasi. Messianisme mengandaikan ada situasi yang ingin dirubah karena dipandang sebagai situasi krisis, penuh dengan penderitaan, kezaliman, dan dekadensi. Ada perbedaan besar yang dirasakan antara konsep yang diidealisasi dengan realitas yang terjadi. Kesadaran akan hal tersebut menimbulkan harapan akan perubahan yang mendatangkan keadilan, kemakmuran, dan regenerasi. Harapan-harapan tersebut seringkali membangkitkan sentimen revolusioner, yang dapat diperkuat oleh ideologi keagamaan, seperti perang sabil melawan orang-orang kafir.

Luwesnya konsep Ratu Adil/Satria Piningit dalam masyarakat Jawa seperti juga dalam gagasan dalam ide Mahdisme Islam membuat banyak orang atau kelompok mengklaim diri sebagai Ratu Adil itu sendiri maupun sebagai orang yang diberi wangsit dari sang Ratu Adil. Salah satu penelitian yang cukup komperehensif memberikan gambaran bagaimana gagasan tentang Ratu Adil diaktualisasikan menjadi tindakan-tindakan dan dikontestasikan sebagai wacana adalah penelitian yang dilakukan oleh Sartono. Fokus Sartono adalah dimensi revolusioner yang terdapat pada gagasan messianistik Ratu Adil yang di masa lalu banyak menimbulkan huruhara dan kerusahan akibat upaya pemberontakan terhadap pemerintahan kolonial Belanda, khususnya sepanjang abad 19.

Sartono mencatat peristiwa-peristiwa pergolakan keagamaan di Jawa pada rentang waktu antara abad 19 sampai dengan abad 20. Pada rentang masa tersebut, beberapa gerakan keagamaan mempunyai corak gerakan messianistis. Gerakangerakan messianistik tersebut banyak didasari oleh semangat-semangat religius, sehingga perjuangan untuk merealisasikan harapan messianistis tersebut dianggap sebagai suatu gerakan 'suci'. Hal ini mungkin membuat kita berfikir bahwa gerakangerakan tersebut cenderung fundamentalis, namun demikian kita harus berhati-hati karena terdapat juga banyak gerakan atau komunitas messianistis yang memakai caracara damai dan terbuka.

Salah satu gerakan yang dicatat Sartono sebagai gerakan yang menggunakan gagasan messianistik adalah pemberontakan pentani Banten pada tahun 1888. Perlu diketahui bahwa yang dimaksudkan oleh Satono sebagai petani bukanlah para petani biasa semata, melainkan juga para pemuka agama, orang-orang kaya dan terhormat di lingkungannya yang menjadi para pemimpin pemberontakan. Para pemimipin inilah yang mengembangkan dan menyebarkan berbagai ramalan dan visi sejarah yang sudah turun temurun mengenai akan datangnya Ratu Adil atau Imam Mahdi ${ }^{34}$. Gerakan ini juga ditandai dengan kebencian terhadap dominasi Belanda dan rasa permusuhan terhadap segala hal yang berbau asing. Hal ini disebabkan oleh rasa ketersingkiran para elit pribumi dalam hirarki sosial dan tatanan politik pemerintahan sejak Belanda mendominasi kekuasaan di daerah mereka. Pada masa-masa ini juga marak kebangkitan dan peningkatan kesalehan beragama yang ditandai dengan 
peningkatan jumlah orang berangkat haji. Dominasi dan penjajahan Belanda diandaikan sebagai sebuah kondisi yang tidak ideal, sebagai sebab kemerosotan masyarakat di berbagai bidang, menjadikan realitas ini sebagai hal yang bertentangan dengan semangat messianisme yang membuat penggunaan wacana messianistik sebagai wacana gerakan menjadi rasional.

Contoh lain yang diberikan Sartono tentang gerakan-gerakan di masa lalu adalah peristiwa pemberontakan Pangeran Diponegoro yang mengambil nama Erucakra, salah tokoh messianis yang diramalkan dalam Pralambang Jayabaya ketika ia memberontak melawan kekuasaan Sultan Amangkurat IV, kira-kira tahun 1720. Pangeran pemberontak termasyhur, Pangeran Diponegoro yang lain kira-kira seabad kemudian juga mempunyai gelar Erucakra. Menurut autobiografinya ia mengaku telah menerima wahyu dari Ratu Adil sendiri, yang menyuruhnya mengusir penguasa asing $^{35}$. Selain itu, juga ada gerakan bernama Kobra (Jumadilkbra) yang berpusat di bagian selatan daerah Pekalongan dan di bagian utara daerah Banyumas, Jawa Tengah. Pelopornya adalah seorang guru agama bernama Ahmad Ngisa yang menyatakan bahwa Syekh Jumadilkubra dari Wanabadra telah memberikan pesan suci kepadanya. Ia meramalkan akan datangnya Erucakra untuk melawan dan mengusir penguasa asing ${ }^{36}$.

Gerakan messianisme biasanya mengkonstruksi tempat-tempat tertentu yang diklaim memiliki karamah tertentu. Pola tersebut telah kita lihat misalnya dalam konsep messianisme Syiah yang mengkultuskan tempat seperti Qum, Kufah, atau Mekkah sebagai tempat yang diyakini sebagai tempat di mana Imam Mahdi akan memulai gerakan revolusionernya. Hal serupa juga dipraktikkan oleh Jamaah anNadzir yang mengkonstruksi Mawang sebagai tanah keramat. Bagi an-Nadzir, Mawang bukan hanya tempat domisili semata, lebih dari itu, Mawang dikonstruksi sebagai tanah pertama di muka bumi ${ }^{37}$. Konstruksi seperti itu sebenarnya adalah hal yang lumrah pada masyarakat Sulawesi Selatan. Beberapa kelompok seperti masyarakat Kajang Kabupaten Bulukumba juga mengklaim bahwa tempat mereka adalah tempat pertama di muka bumi. Klaim seperti itu biasanya diperebutkan untuk mendapatkan legitimasi lokal sebagai daerah yang suci dan bersahaja.

Pengkultusan terhadap tempat-tempat tertentu adalah bagian dari konstruksi dan representasi dari wacana messianistik yang mereka bangun. Jamaah an-Nadzir meyakini bahwa Mawang adalah tempat di mana Imam Mahdi yang dinantikan akan muncul. Klaim ini mereka dasarkan pada dalil teologis bahwa Imam Mahdi akan muncul dan memulai suksesi kepemimpinannya dari wilayah 'timur'. Oleh an-Nadzir, 'timur' mereka pahami sebagai daerah Mawang sebab dalam pandangan mereka tidak ada lagi komunitas yang mempraktikkan ajaran Nabi Muhammad secara konsisten di 'timur' selain mereka ${ }^{38}$.

Beragamnya konstruksi messianisme dalam kelompok-kelompok Islam disebabkan dalil-dalil teologis yang mengambang sehingga sangat terbuka untuk berbagai macam interpretasi. Upaya merebut makna tentang 'timur' seperti yang dilakukan oleh Jamaah an-Nadzir dan juga gerakan messianisme Islam lainnya didasarkan pada hadist-hadist berkaitan dengan eskatologi Islam yang menyebutkan bahwa mesias Islam akan datang dari arah timur dari kalangan non Arab. Selain Jamaah an-Nadzir, konstruksi serupa telah lama dikampanyekan oleh komunitas- 
komunitas Syiah di Iran. Interpretasi-interpretasi yang dibentuk oleh berbagai kelompok Islam itu merupakan sebuah konstruksi untuk mengafirmasi konsep-konsep messianistik yang mereka yakini. Sebagai sebuah konstruksi konsep-konsep tersebut tidak bisa dilepaskan dari muatan-muatan politis dan pertarungan wacana di dalamnya.

Konsep messianisme an-Nadzir dibangun dari klaim-klaim eskatologi Islam. Berbicara mengenai konsep-konsep teologi Islam -termasuk permasalahan konsep messianisme- mungkin sangat sulit tanpa melibatkan konsep teologi yang dibangun oleh kelompok Sunni-Syiah sebagai dua kelompok Islam terbesar apalagi jika kita membicarakannya dalam konteks komparasi untuk melihat kompleksitas dari berbagai konstruksi yang berbeda itu.

Jamaah an-Nadzir bagaimanapun juga terpengaruh dan menggunakan konsep Syiah maupun Sunni pada seluruh wacana dan praktik teologi mereka. Meski demikian, Jamaah an-Nadzir memodifikasi dan menggabungkan kedua konsep tersebut untuk membangun sebuah konsep yang 'khas' mereka. penggabungan konsep Sunni dan Syiah membuat konsep messianisme an-Nadzir tidak identik dengan keduanya dan sekaligus membentuk konstruksi identitas yang berbeda. Bagaimanapun juga, messianisme adalah sebuah medan pertarungan wacana yang bersifat hitam putih, yang ingin direbut dan dimapankan adalah klaim siapa yang paling 'benar'. Olehnya itu, pembedaan konstruksi identitas 'aku' dan 'kamu', 'kita' dan 'mereka' seperti menjadi sesuatu yang mutlak dibutuhkan.

Sebagaimana lazimnya mayoritas umat Islam, Jamaah an-Nadzir meyakini mesias akhir zaman adalah Imam Mahdi. Imam Mahdi dipercayai adalah keturunan nabi Muhammad (ahlulbait) dari pernikahan Ali bin Abi Thalib dengan Fatimah, putri nabi Muhammad. Namun demikian, Jamaah an-Nadzir memberi nuansa lokal dalam konstruksi mereka tentang siapa Imam Mahdi itu. Jamaah an-Nadzir meyakini bahwa Imam Mahdi telah lahir dan pernah eksis di bumi ini, mereka mempercayai bahwa Imam Mahdi lahir sekitar tahun 250 hijriah dan mengalami beberapa periode kegaiban $^{39}$.

Kegaiban pertama terjadi ketika Imam masih kecil yang disebut sebagai ghaib shugra. Imam Mahdi dalam kepercayaan Jamaah an-Nadzir kemudian mewujud dalam sosok Kahar Muzakkar, pemimpin gerakan DI/TII di Sulawesi Selatan. Imam Mahdi kemudian muncul lagi dalam sosok pendiri Jamaah an-Nadzir, Kyai Syamsuri Abdul Madjid. Ketika Kyai Samsuri meninggal pada tahun 2006, peristiwa itu diklaim oleh an-Nadzir sebagai ghaib kubra. Imam Mahdi dipercayai akan muncul lagi untuk menebarkan keadilan ke seluruh penjuru bumi melalui penegakan hukum ilahi setelah sekian lama dunia dianggap dipenuhi oleh berbagai macam kebatilan ${ }^{40}$.

Konstruksi an-Nadzir tentang Imam Mahdi yang demikian itu sangat mirip dengan konstruksi Syiah yang sama-sama meyakini bahwa Imam Mahdi telah lahir dan mengalami beberapa periode kegaiban. Berkebalikan dengan konstruksi Syiah dan an-Nadzir, kelompok Sunni meyakini bahwa Imam Mahdi belum pernah dilahirkan ke dunia, bahkan sebagian kelompok Sunni meyakini bahwa Imam Mahdi sesungguhnya adalah Isa ibnu Maryam (Yesus) yang akan kembali lagi ke muka bumi dengan membawa agama Muhammad. 
Meskipun memiliki kemiripan dengan kepercayaan messianisme Syiah, namun gagasan messianisme Jamaah an-Nadzir tidak sepenuhnya sama dengan konsep messianisme Syiah. Jamaah an-Nadzir memodifikasi konsep messianisme dan eskatologi Islam -Sunni dan Syiah- untuk mengkonstruksi konsep messianistik baru yang hanya identik dengan komunitas mereka. Jamaah an-Nadzir meyakini bahwa Imam Mahdi beberapa periode kegaiban. Pertama yaitu ketika Imam Mahdi masih kecil, kemudian Imam Mahdi muncul lagi menurut Jamaah an-Nadzir dalam diri Kahar Muzakkar, lalu kemudian Imam Mahdi terhijab seiring dengan menghilangnya -ataupun meninggalnya- Kahar Muzakkar. Imam Mahdi kemudian muncul lagi dalam sosok Imam Syamsuri Madjid (pendiri jamaah an-Nadzir), lalu kemudian terhijab lagi pada tahun 2006 ketika Syamsuri Madjid meninggal. Fase terhijab ini juga dianggap sebagai gaib kubra di mana setelah kegaiban tersebut Imam Mahdi akan muncul dalam wujud 'aslinya' untuk memenuhi janji Tuhan.

Penggunaan sosok Kahar Muzakkar sebagai tokoh yang dikaitkan ataupun diklaim sebagai al-Mahdi adalah sebuah hal yang menarik. Bagaimana pun juga Kahar Muzakkar adalah seorang tokoh yang kontroversial. Dia adalah serang tokoh pejuang sekaligus pemberontak karena pernah dianggap melakukan upaya makar terhadap NKRI, sosok yang banyak dibenci sebagian kalangan masyarakat, tetapi tidak sedikit pula yang mencintai dan menaruh simpati terhadap perjuangannya.

Nama asli Kahar Muzakkar adalah La Domeng. Lahir di desa Lanipa, Palopo, Luwu, Sulawesi Selatan pada tanggal 24 Maret 1921. Ayahnya bernama Malinrang adalah seorang petani yang cukup mampu dan tergolong aristokrasi rendah. Dengan kedudukan dan kemampuan orang tuanya, ketika usianya sudah mencapai tujuh belas tahun ia dikirim ke Surakarta untuk belajar di sekolah perguruan Islam Keekschool Muhammadiyah, dari 1938- sampai $1941^{41}$. Selama menjalani masa pendidikannya di Surakarta, Kahar Muzakkar terlibat aktif dalam berbagai organisasi diantaranya menjadi salah seorang pemimpin lokal Pemuda Muhammadiyah di Hizbulwathan, sebuah gerakan kepanduan Muhammadiyah.

Setelah menyelesaikan pendidikannya, Kahar Muzakkar sempat kembali ke daerah asalnya di Sulawesi. Namun karena pengaruh Islam modernis yang dibawanya, Kahar Muzakkar berselisih paham dengan kepala dan tokoh-tokoh adat setempat. Kahar oleh sebagian kepala adat dianggap telah mengutuk sistem feodal yang berlaku di Sulawesi Selatan dan menganjurkan dihapuskannya aristokrasi yang membuat para tokoh adat marah. Dia pun akhirnya dihukum dibuang dari Sulawesi Selatan. Setelah itu, Kahar Muzakkar akhirnya kembali lagi ke Surakarta pada tahun 1943.

Kahar Muzakkar merupakan tokoh yang paradoks. Dia adalah seorang pejuang sekaligus pemberontak. Dalam perjalanan perjuangannya, dia merupakan salah seorang pengawal Soekarno ketika Soekarno menyampaikan salah satu pidato rapat umumnya di lapangan Merdeka Jakarta, 19 September $1945^{42}$. Sebelum melakukan tindakan separatif (baca; pemberontakan), Kahar Muzakkar adalah seorang anggota Tentara Nasional Indonesia. Bahkan, latar belakang ketentaraannyalah yang menjadi pemicu awal pemberontakannya. Kahar Muzakkar kecewa karena tuntutannya untuk menjadikan seluruh tentara gerilyawan yang berperang merebut kemerdekaan di wilayah Sulawesi sebagai tentara Nasional Indonesia dan hak historisnya untuk memimpin pasukan Tentara Nasional Indonesia di Sulawesi Selatan sebagai seorang 
perwira senior tidak dipenuhi pemerintah. Penolakan pemerintah dikarenakan oleh latar pendidikan -formal maupun militer- sebagian besar para mantan gerilyawan revolusi kemerdekaan tersebut dianggap tidak mempunyai kualifikasi pendidikan yang baik untuk dijadikan sebagai prajurit Tentara Nasional Indonesia. Pemerintah Indonesia saat it, lebih memilih para prajurit yang pernah mengenyam pendidikan Eropa untuk dijadikan sebagai tentara -khususnya untuk posisi-posisi strategisdibanding dengan para mantan gerilyawan revolusi kemerdekaan yang hanya mengeyam pendidikan 'tradisional'. Pendidikan tradisional yang dimaksud di sini termasuk pula pendidikan Islam.

Kekecawan Kahar Muzakkar dan para kelompok gerilyawan revolusi kemerdekaan terhadap sikap pemerintah membuat mereka mengundurkan diri ke hutan untuk membagun perlawanan gerilya baru. Bedanya jika dulu gerilya dilakukan untuk melawan Belanda, gerilya kali ini adalah untuk melawan rezim pemerintah Indonesia saat itu. Dalam perjalanan pemberontakannya, Kahar Muzakkar dan pasukan gerilyawannya kemudian menjadikan isu Islam sebagai wacana gerakannya. Pada tahun 1953 Kahar Muzakkar menyatakan bahwa Sulawesi Selatan dan daerah Indonesia Timur lainnya sebagai bagaian dari Negara Islam Indonesia (NII) bentukan SM Kartosuwiryo. Bersamaan dengan itu, ia juga mengganti nama pasukannya dengan nama Tentara Islam Indonesia ${ }^{43}$. Dengan menggunakan Islam, Kahar Muzakkar mulai memungut berbagai pajak dari masyarakat seperti pajak pembangunan, pajak perjuangan, pajak ternak dan pajak pendapatan atas nama Negara Islam Indonesia ${ }^{44}$. Gerakan Islam yang diusung oleh Kahar cenderung bersifat puritan. Dia sangat membenci sistem feodal, olehnya itu Kahar Muzakkar melarang pemakaian gelar kebangsawanan seperti Andi dan Daeng untuk menciptakan masyarakat setara yang dibayangkannya. Hal tersebut membuatnya banyak dibenci kalangan bangsawan. Selain itu, Kahar dan pasukannya juga menyerang paham mistik-mistik masyarakat pra Islam di Sulawesi Selatan. Para tokoh spiritual pra Islam seperti komunitas Bissu disingkirkan. Hukum Islam (syariat) dijadikan sebagai tonggak utama dalam penataan masyarakat.

Selain dekat dengan wacana Islam, Kahar Muzakkar sendiri sebenarnya dekat dengan wacana Marxisme. Islam sepertinya memberi keuntungan lebih besar terhadap gerakannya. Melalui wacana Islam, Kahar memperoleh banyak dukungan dari kalangan bangsawan yang juga merasa kecewa dengan pemerintah ${ }^{45}$, hal yang mana dirasa akan hilang jika marxisme yang dijadikan sebagai wacana utama gerakan. Kahar berusaha mempertahankan dukungan mereka tanpa mengorbankan tujuan untuk mencapai keadilan sosial. Islam dengan prinsip persamaan haknya juga dapat digunakan sebagai serangan tak langsung terhadap feodalisme ${ }^{46}$. Gerakan Kahar Muzakkar juga hampir tidak bisa dilepaskan dari sentimen kedaerahan saat itu. Dalam hal ini, Islam dipakai sebagai antagonisme antara 'kita' dan 'mereka'. 'kita' adalah para pemberontak yang merupakan putra asli daerah, sedang 'mereka' adalah orangorang Kristen Minahas dan orang abangan- jika istilah ini masih bisa dipakai- Jawa yang banyak menduduki jabatan-jabatan publik penting di Sulawesi Selatan saat itu yang sekaligus adalah lawan di medan pertempuran ${ }^{47}$.

Pemberontakan Kahar Muzakkar berlangsung pada rentang waktu antara tahun 1950 sampai dengan tahun 1965. Melalui serangkaian operasi militer panjang untuk 
meredam pemberontakannya, gerakan Kahar Muzakkar dan pasukan akhirnya dapat diakhiri. Kahar Muzakkar sendiri dinyatakan tewas tertembak pada tanggal 3 Februari 1965 di tangan pasukan divisi Siliwangi yang dikirim khusus menghabisi gerakannya. Namun demikian jasad dan makamnya tak pernah dipublikasi secara jelas kepada masyarakat.

Kesimpangsiuran berita kematian Kahar Muzakkar membuat banyak orang berspekulasi dan pada akhirnya dimistifikasi. Mistifikasi tersebut membuat wacana tentang sosok Kahar dapat dibawa kemana saja. Beberapa orang (termasuk beberapa mantan anggota pasukannya) meyakini bahwa Kahar tidak meninggal pada saat operasi militer tahun 1965 tersebut, dia dianggap sosok yang kebal peluru. Kesamaran tentang berita kematian Kahar inilah yang sepertinya digunakan oleh Syamsuri Madjid untuk mendapatkan simpati masyarakat ketika dia melakukan dakwahnya di Luwu, Sulawesi Selatan.

Seperti telah disebutkan di atas, Jamaah an-Nadzir meyakini bahwa sebelum muncul dalam sosok 'aslinya' Imam mahdi telah mewujud dalam sosok Kahar Muzakkar dan Syamsuri Madjid. Penggunaan sosok Kahar Muzakkar dimungkinkan karena kesamaan cita-cita menegakkan hukum Islam secara kaffah meski an-Nadzir tidak memahaminya dalam konteks Negara sebagaimana dicita-citakan Kahar. Annadzir memahami dan menciptakan konstruksi tentang penegakan Hukum Islam dalam wacana doktrin eskatologi Islam sebagai upaya pemenuhan janji ilahi dan percepatan kedatangan sosok messianis, Imam Mahdi. Sosok Kahar juga sangat mungkin digunakan sebagai wacana politis meraih simpati masyarakat. Bagaimanapun komunitas an-Nadzir di Sulawesi Selatan bermula dari kabupaten Luwu, sebuah distrik yang merupakan basis pendukung loyalis dan pusat perjuangan Kahar Muzakkar di masa lalu.

Dengan mewacanakan sosok Kahar dan Syamsusi sebagai Imam Mahdi membuat penyamaan sosok Syamsuri sebagai Kahar tak dapat dihindari. Bahkan pada awalnya Syamsuri tidak menolak anggapan ini $^{48}$. Pengakuan Syamsuri sebagai sosok Kahar Muzakkar menimbulkan polemik di antara keluarga Kahar. Keluarga besar Kahar akhirnya meminta Syamsuri membuat pernyataan tertulis bahwa dirinya bukanlah Kahar Muzakkar. Syamsuri akhirnya memenuhi permintaan itu. Tepatnya pada 5 Januari 2001 Syamsuri menyatakan 'saya adalah Syamsuri Abdul Madjid dan Kahar Muzakkar adalah Kahar Muzakkar yang sama kita ketahui telah meninggal dunia"49. Meskipun telah menyatakan bahwa dia bukan Kahar, namun doktrin messianis tentang Imam Mahdi masih menggunakan sosok Kahar maupun Syamsuri tersebut dalam penciptaan wacana messianistis an-Nadzir hingga saat ini.

Penggunaan unsur narasi dan tokoh kharismatik lokal dalam konstruksi messianisme Jamaah an-Nadzir selain dilakukan untuk kepentingan pembedaan indentitas dengan konstruksi messianisme Syiah juga sangat mungkin dipenuhi dengan muatan politis untuk meraih simpati masyarakat lokal, Kyai Samsuri dikonstruksi sebagai jelmaan Kahar Muzakkar yang dianggap perwujudan Imam Mahdi. Bagaimanapun juga kabupaten Luwu yang menjadi basis awal gerakan Jamaah an-Nadzir dikenal luas sebagai basis loyalis Kahar dan mengkultuskannya sebagai sosok yang menmpunyai kemampuan supranatural. Selain itu, gerakan Kahar yang berhasrat mendirikan sebuah Negara berlandaskan hukum Islam memiliki 
kedekatan dengan semangat an-Nadzir yang berusaha menghidupkan kembali kehidupan kenabian meski Jamaah an-Nadzir tidak atau belum memahaminya dalam konteks pendirian sebuah negara Islam.

Pembicaraan mengenai gerakan messianisme tidak bisa dilepaskan dari peran tokoh-tokoh kharismatik. Peran tokoh kharismatik menjadi hal sentral karena sebuah gerakan messianistis biasanya dimulai dengan klaim seorang tokoh kharismatik dan diamini oleh pengikutnya yang mengklaim diri sebagai pengejawantahan dari sebuah konsep messianisme tertentu entah itu dari konsep messianisme lokal maupun konsep messianisme yang berkaitan dengan konsep eskatologi agama.

Keberadaan seorang tokoh kharimatik ini seolah menjadi syarat utama sebuah konsep messianisme dapat mewujud sebagai sebuah 'praktik'. Dalam konteks Jamaah an-Nadzir, peran sebagai tokoh kharismatik itu disandarkan pada sosok Kyai Samsuri yang dianggap sebagai jelmaan Imam Mahdi. Setelah Kyai Samsuri meninggal, peran tersebut diambil oleh Ustad Rangka yang mengklaim diri sebagai sosok Pemuda Bani Tamim.

Berbeda dengan doktrin messianis lainnya, konstruksi messinistik Jamaah anNadzir lebih berpusat pada sosok yang akan mempersiapkan kemunculan dan revolusi Imam Mahdi, bukan pada klaim tentang sosok al-Mahdi Sosok yang dimaksud jamaah an-Nadzir adalah seseorang yang dijuluki Pemuda Bani Tamim. Pemuda Bani Tamim dalam pandangan an-Nadzir adalah tokoh sentralitas ${ }^{50}$ dunia di akhir zaman. Dia merupakan sosok pemimpin akhir zaman yang akan mendahului dan mempersiapkan syarat-syarat bagi terciptanya revolusi ilahi oleh Imamul 'Azdma Al-Mahdi AlMuntazar' ${ }^{51}$. Sebagaimana al-Mahdi, Pemuda Bani Tamim juga diwacanakan sebagai sosok pilihan ilahi. Hal tersebut bahkan sudah ditunjukkan dari pemilihan namanya. Tamim dalam bahasa Arab bermakna sempurna. Menurut Ustad Rangka (pemimpin Jamaah an-Nadzir) ukuran kesempurnaan manusia adalah jika dia telah mengenali tuhannya dan bertemu dengannya. Pemuda Bani Tamim menurut klaim Rangka telah sempurna keimanannya kepada tuhan karena telah bertemu dengan Tuhan sebagaimana yang pernah dialami Muhammad pada peristiwa Isra Mi'raj ${ }^{52}$.

Pemuda Bani Tamim dalam konstruksi an-Nadzir disamakan dengan sosok Satria Piningit" atau "Ratu Adil dalam messianisme Jawa. Namun an-Nadzir menegasi kemungkinan kemunculan sosok messianis dari Jawa. tidak seperti dalam konsep messianistis Jawa di mana wacana messianitis tidak selalu harus sepenuhnya teologis-eskatologis tetapi sangat mungkin juga dalam wacana politik, an-Nadzir memandang dan memahami messianisme dalam wacana yang sangat teologis (meski bukan berarti tidak politis). Dalam pandangan an-Nadzir, di tanah Jawa tidak akan muncul sosok messiah karena di Jawa sudah dipenuhi dengan berbagai kemaksiatan dan ketiadaan sebuah komunitas ummah yang secara konsisten menjalankan Islam secara 'benar'. Negasi an-Nadzir ini sedikit banyak menyerupai sentimen kedaerahan yang dijadikan wacana dalam pemberontakan Kahar Muzakkar di masa lalu, dengan menegasikan Jawa, Jamaah an-Nadzir sekaligus juga berusaha memapankan citra yang mereka konstruksi seputar komunitasnya.

Menurut mereka, Pemuda Bani Tamim adalah seseorang yang dijuluki "Assa'na Gowa" atau aslinya Gowa. Ia adalah keturunan Raja dari Polong Bangkeng Gowa yang memakai nama gelar "Daey". Lebih lanjut, an-Nadzir menghubung- 
hubungkan klaim mereka tentang Pemuda Bani Tamim dengan tokoh ulama kharismatik Sulawesi Selatan, Syekh Yusuf al-Makassari. Pemuda Bani Tamim diklaim masih dari keturunan keluarga Syehk Yusuf yang merupakan keturunan dari Nabiullah Khaidir Ibnu Abbas Balyamulkan Rije'ma Alfahanisu Al-Ajiru Abul Abbas Balyamulkan as. tapi ia bukan anak keturunan dari Syaikh Yusuf, melainkan beliau berasal dari keturunan anak cucu yang ketujuh dari Nabiullah Khaidir as, salah seorang dari keturunan inilah yang dipilih oleh Allah SWT untuk menjadi Pemuda Bani Tamim ${ }^{53}$. Dalam berbagai naskah kuno Sulawesi Selatan, Syekh Yusuf memang dimistifikasi sebagai anak dari tokoh mistis Nabi Khidir yang memiliki berbagai karamah sejak dia dilahirkan. ${ }^{54} \mathrm{Hal}$ itu dilakukan untuk memberi legitimasi kuat terhadap kewalian dan kekaramahan Syehk Yusuf yang menjadi wacana sentral dalam masyarakat Sulawesi Selatan.

Siapakah Pemuda Bani Tamim itu dalam eksistensinya saat ini? Jamaah anNadzir tidak secara pasti menyebutkan tokoh tertentu, namun dalam berbagai kesempatan, secara tersirat klaim tersebut disematkan kepada pemimpin mereka saat ini, Ustad Rangka. Misalnya dalam sebuah wawancara Ustad Rangka berkata

"Saya tahu siapa itu Pemuda Bani Tamim, aku sangat kenal dengannya. Aku sering tidur dengannya, apa yang aku makan itu pulalah yang dia makan",55.

Dalam berbagai kesempatan pula, Ustad Rangka sering menggunakan wacana mistis tentang kekebalan ketika diajak berargumentasi tentang konsep aqidah

"Kalau kau yakin Tuhanmu Allah, kau yakin bahwasanya Allah yang cabut nyawamu kalau kau mati, sekarang kau tebas saya duluan, setelah itu gantian saya yang tebasko, betul dak aqidahmu dak melenceng, maksudnya bukan parang ini yang cabut nyawamu" 56 .

Terdapat beberapa hal menarik pada seputar pembentukan wacana tentang Pemuda Bani Tamim an-Nadzir. Hal itu terlihat dari klaim tentang gelar bangsawan Makassar (Gowa) 'daey' yang mereka sebut yang sama sekali tidak terdapat atau tidak pernah ditercatat dalam sejarah tradisi suku Makassar di Sulawesi Selatan. Sepanjang catatan sejarah, suku Makassar tidak pernah mengenal gelar 'daey' sebagai nama untuk gelar kebangsawanan Makassar. Gelar kebangsawanan Makassar biasanya dikenal dengan sebutan Karaeng atau Daeng. Dalam stratifakasi masyarakat Makassar di masa lalu, manusia dibagi menjadi tiga tingkatan yaitu Karaeng, Tu Maradeka, dan $\mathrm{Ata}^{57}$. Karaeng adalah kelas sosial atas yang dihuni oleh para bangsawan. Tu Maradeka adalah lapisan masyarakat kelas menengah yang biasanya merupakan jumlah kelas sosial mayoritas. Sedangkan ata adalah budak atau abdi. klaim tentang kebangsawanan tersebut juga terkesan paradoks, karena kebangsawanan dalam masyarakat Bugis-Makassar bukanlah sesuatu yang kaku, setiap orang berpotensi untuk 'naik kelas' sosial menjadi bangsawan meskipun dia sebenarnya bukan dari kelas tersebut dengan berbagai cara semisal perkawinan dan sebagainya $^{58}$.

Hal lain yang menarik dari konstruksi wacana seputar Pemuda bani Tamim jamaah an-Nazdir adalah pernyataan tentang relasi pemuda Bani Tamim dengan ulama kharismatik, Syekh Yusuf. Hal tersebut tampak tipikal dengan pengasimilasian tokoh Kahar Muzakkar dengan sosok Mahdi ${ }^{59}$. Hal itu menunjukkan bagaimana an- 
Nadzir banyak menggunakan narasi lokal yang telah melekat namun samar-samar dalam konstruksi messianis mereka. konstruksi tentang Kahar Muzakkar dibangun ketika basis Jamaah an-Nazdir masih berada di kabupaten Luwu- tanah kelahiran dan basis Kahar pada masa pemberontakannaya- sewaktu pemimpin mereka Syamsuri Madjid masih hidup- tokoh yang diklaim reinkarnasi Kahar. Sementara ketokohan Syehk Yusuf dipergunakan ketika komunitas ini telah mapan di Mawang Kabupaten Gowa. Hal tersebut sepertinya bertujuan untuk mengangkat sosok Ustad Rangka, pemimpin komunitas yang juga merupakan warga Gowa.

Dengan membangun kontruksi messianis semacam itu, jamaah an-Nadzir menempatkan konstruksi messianis mereka dalam sebuah medan kontestasi. Setiap konstruksi mesianistis pastilah menyatakan bahwa klaim merekalah yang 'benar'. Jamaah an-Nadzir menegasikan potensi messias dari Jawa, selain itu mesti banyak memakai doktrin messianis Syiah dalam konstruksi messianis mereka, namun mereka pula menolak klaim Syiah khususnya berkaitan dengan pemuda Bani Tamim. Penolakan ini bukan sekadar karena menganggap diri berbeda dengan Syiah, melainkan juga menentukan konstruksi lanjutan mereka berkaitan dengan tempat kemunculan komunitas pilihan calon pembela sang Mahdi.

Jamaah an-Nadzir menerapkan konsep kepemimpinan imamah. Untuk menjamin konsep imamah tersebut, Jamaah an-Nadzir menerapkan sistem baiat, yaitu pernyataan kesetiaan, ketaatan, dan kepercayaan bahwa apa yang diajarkan oleh pemimpin tertinggi (imam) adalah benar. Sistem kepemimpinan seperti sangat kental kultus individu yang mengkonstruksi bahwa sang imam adalah wakil Tuhan di muka bumi.

Konsep kepimpinan imamah adalah konsep lazim dalam wacana kepemimpinan Islam meski dengan interpretasi yang berbeda-beda di antara kelompok-kelompok Islam. Wacana kepemimpinan dalam Islam merupakan sebuah masalah pelik dan kompleks, bahkan wacana tersebut menjadi penyebab utama lahirnya sekte-sekte Islam sejak masa- masa awal sejarah Islam. Konsep imamah anNadzir lebih mirip dengan konsep imamah Syiah meski mereka lebih memilih menggunakan dalil dalil Sunni dalam mengafirmasi konstruksi mereka. Pemilihan sebuah dalil dalam wacana Islam -terutama hadist- adalah sesuatu yang sangat politis dalam Islam karena menunjukkan orientasi teologis dan politik sebuah kelompok. Hal ini sekali menunjukkan unsur kreasi dan pembedaan identifikasi diri Jamaah anNadzir.

Apa yang dipraktikkan oleh jamaah an-Nadzir dengan mengkonstruksi diri berbeda dengan kelompok-kelompok Islam mulai dari cara berpakaian sampai konsep messianisme mereka adalah upaya untuk menciptakan sebuah representasi wacana messianistik 'baru'. Tampilan fisik dan busana berpakaian yang berbeda digunakan untuk mengklaim bahwa mereka adalah kelompok yang paling benar dalam meneladani ajaran 'asli' nabi Muhammad. Serangan bahwa apa yang mereka yakini berbeda dengan Islam mainstream khususnya dalam konteks Indonesia malah digunakan untuk mengafirmasi klaim 'keaslian' mereka dengan mengatakan bahwa Islam datang sebagai sesuatu yang asing dan di akhir zaman akan kembali menjadi asing meski bukan dalam artian kuantitas. Anggapan bahwa praktik mereka 
menyimpang dibalikkan dengan membangun konstruksi bahwa mereka adalah kelompok kecil yang menjalankan Islam yang 'asli'.

Konstruksi cara berpakaian an-Nadzir selain sebagai bentuk penciptaan klaim messianistik dan pembedaan diri dengan kelompok Islam lain juga merupakan meminjam bahasa Foucault- sebuah mekanisme pendisiplinan diri. Dengan tampilan fisik dan cara berpakaian demikian, seorang anggota Jamaah an-Nadzir akan selalu merasa harus mencitrakan diri sebagaimana konsep teologis yang mereka yakini. Pakaian tersebut menjadi elemen panoptik yang membuat mereka selalu bertindak dalam batas-batas konstruksi mereka.

Selain melalui politik berbusana, mekanisme pendisiplinan diri (tubuh) lain yang juga dipraktikkan oleh Jamaah an-Nadzir adalah melalui konsep imamah yang mengharuskan baiat dalam penerapannya. Dengan berbaiat, seorang jamaah menyatakan kepatuhan dan kepercayaan sepenuhnya terhadap apa yang diajarkan oleh pemimpinnya. Metode ini menjamin kesetiaan jamaah, sebab metode kepemimpinan kultus individu itu, pengingkaran terhadap imam dapat dianggap sebagai pengingkaran terhadap kehendak Tuhan karena imam adalah wakil Tuhan di muka bumi.

Upaya pembentukan konstruksi messianisme yang berbeda oleh jamaah anNadzir dapat dilihat sebagai sebuah pembentukan wacana-pengetahuan baru dalam gelanggang pertarungan konsep-konsep messianistik. Jamaah an-Nadzir menggunakan klaim-klaim eskatologi Islam yang diinterpretasikan secara mandiri untuk mengafirmasi konstruksi messianisme yang mereka bangun. Selain dari sumber teks-teks suci tersebut, Jamaah an-Nadzir juga menggunakan dengan sangat cerdik narasi lokal yang mereka berikan nuansa interpretasi baru. Bisa dikatakan an-Nadzir membangun konsep pengetahuan narasi lokal masa lalu tersebut untuk membentuk sebuah ekspektasi dan orientasi masa depan.

\section{E. Kesimpulan}

Anggota jamaah an-Nadzir, sebagian besar di Mawang bukan hanya orang lokal, masyarakat Kabupaten Gowa, melainkan datang dari berbagai wilayah di Indonesia. Semangat messianistis yang menyatukan anggotanya sehingga rela meninggalkan kampung halaman, pekerjaan, dan bahkan keluarga untuk mendirikan sebuah komunitas mandiri dalam rangka mewujudkan cita-cita messianik yang mereka percayai.

Konsep messianisme an-Nadzir dibangun dari klaim-klaim eskatologi Islam. Jamaah an-Nadzir terpengaruh dan menggunakan konsep Syiah maupun Sunni pada seluruh wacana dan praktik teologi mereka. Meski demikian, Jamaah an-Nadzir memodifikasi dan menggabungkan kedua konsep tersebut untuk membangun sebuah konsep yang 'khas' mereka. Penggabungan konsep Sunni dan Syiah membuat konsep messianisme an-Nadzir tidak identik dengan keduanya dan sekaligus membentuk konstruksi identitas yang berbeda.

Jamaah an-Nadzir meyakini mesias akhir zaman adalah Imam Mahdi. Imam Mahdi dipercayai adalah keturunan nabi Muhammad (ahlulbait) dari pernikahan Ali bin Abi Thalib dengan Fatimah, putri Nabi Muhammad, namun demikian, Jamaah anNadzir memberi nuansa lokal dalam konstruksi mereka tentang siapa Imam Mahdi itu. 
Imam Mahdi menurut Jamaah an-Nadzir mewujud dalam sosok Kahar Muzakkar, pemimpin gerakan DI/TII di Sulawesi Selatan. Imam Mahdi kemudian muncul lagi dalam sosok Kyai Syamsuri Abdul Madjid. Ketika Kyai Samsuri meninggal pada tahun 2006, peristiwa itu diklaim oleh an-Nadzir sebagai ghaib kubra. Imam Mahdi dipercayai akan muncul lagi untuk menebarkan keadilan ke seluruh penjuru bumi melalui penegakan hukum ilahi setelah sekian lama dunia dipenuhi oleh berbagai macam kebatilan.

Messianisme an-Nadzir adalah sebuah usaha penciptaan sebuah wacana/kekuasaan di antara konsep messiniasme lainnya. Seperti kata Michel Foucault, where there is power, there is resistance ${ }^{60}$. Kekuasaan itu tersebar di manamana, bukan sesuatu yang dimiliki. Messianisme an-Nadzir juga dapat dipandang sebagai perlawanan atas wacana messianisme yang telah lebih dulu mapan. Pada akhirnya messianisme adalah sebuah medan kontestasi yang sangat terbuka. Berbagai macam interpretasi dan klaim menjadi sesuatu yang sulit dihindari. Sebagai sebuah medan kontestasi, messianisme menghadirkan berbagai macam wacana dan relasi kekuasaan. 


\section{Endnote}

${ }^{1}$ Sebagai contoh Durkheim misalnya mengatakan bahwa konsekuensi dari semakin dinamis dan beragamnya Division of Labour menyebabkan perubahan skema solidaritas, dari solidaritas mekanik ke solidaritas organik. Di dalam solidaritas organik yang menjadi ciri masyarakat 'modern', masyarakatnya lebih individual. Pola ini juga memengaruhi kehidupan beragama sebagai salah satu institusi pembentuk moralitas. Dengan menjadi masyarakat yang lebih individual Durkheim seperti mengimajikan bahwa peran agama juga akan berkurang dalam masyarakat modern. Selain Durkheim, Weber juga kurang lebih punya pandangan yang sama. Dalam bukunya The The Protestant Ethic and the 'Spirit' of Capitalism weber menyebut tiga pola otoritas yaitu otoritas tradisonal, kharismatik, dan rasional. Otoritas tradisional dan karismatik dapat dikatakan berkaitan erat dengan tradisi keagamaan. Weber meramalkan bahwa pada akhirnya masyarakat akan menuju pada otoritas rasional yang dalam arti tertentu berarti berkurangnya otoritas keagamaan dalam masyarakat modern.

${ }^{2}$ Lihat Talal Asad. Formations of the Secular: Christianity, Islam, Modernity (Cultural Memory in the Present). Stanford, California: Stanford University Press, 2003), dan Peter L. Berger, The Desecularization of the World (Grand Rapids: Eerdmans. 1999)

${ }^{3}$ Lihat Peter L Berger, Kebangkitan Agama Menantang Politik Dunia (Yogyakarta: Penerbit Ar-Ruzz, 2003), h. 32.

${ }^{4}$ Studi-studi akademik tentang kekerasan terhadap syiah di sampang di antaranya dapat dilihat melalui tulisan berikut ini. Afdillah, Muhammad. Dari Masjid ke Panggung Politik: Studi Kasus Peran Pemuka Agama dan Politisi dalam Konflik Kekerasan Agama antar Komunitas Sunni dah Syiah di Sampang Jawa Timur, tesis Sekolah Pascasarjana Program Studi Agama dan Lintas Budaya, Universitas Gajah Mada, Yogyakarta. 2013, dan Akmaliah, Wahyudi. "Kekerasan dan Pengusiran Atas Nama Agama Pasca Rejim Orde Baru: Studi Kasus Konflik Syiah Sampang”, dalam Jurnal Maarif Institute, Vol. 10, No. 2. 2015.

${ }^{5}$ Lihat Haryatmoko, Dominasi Penuh Muslihat: Akar Kekerasan dan Diskriminasi' (Jakarta: Gramedia, 2010), h. 83.

${ }^{6}$ Lihat Sartono, Ratu Adil, Sinar Harapan, 1984, h. 10

${ }^{7}$ Lihat Sartono Kartodirdjo, Catatan Tentang Segi-segi Messianistis dalam Sejarah Indonesia (Universitas Gadja Mada, 1959), h. 7.

${ }^{8}$ Manuskrip sejarah yang biasanya berkaitan dengan masyarakat, tokoh, atau sejarah kerajaan yang ditulis dalam aksara lokal

${ }^{9}$ Lihat Mattulada, LATOA: Satu Lukisan Analitis Terhadap Antropologi Politik Orang Bugis (Hasanuddin University Press, 1995), h. 416.

${ }^{10}$ Lihat Eric Hobsbawm\&Terence Ranger, The Invention Of Tradition (Cambridge University Press, 1983), h. 1.

${ }^{11}$ Lihat William E. Deal and Timothy K. Beal, Theory for Religious Studies (Routledge, 2005), h. 72.

${ }^{12}$ Lihat Foucault, The History of Sexuality, Vol I: An Introduction (New York: Vintage, 1978), h. 11.

${ }^{13}$ Lihat Haryatmoko, Kekuasaan Melahirkan Anti-Kekuasaan, h. 2 . 
1978), h. 93.

${ }^{14}$ Lihat Foucault, The History of Sexuality, Vol I: An Introduction (New York: Vintage,

${ }^{15}$ Lihat Foucault, The History of Sexuality, h. 92.

${ }^{16}$ Lihat K. Bertens, Filsafat Barat Perancis, Gramedia Pustaka Utama, 2001, h. 320

${ }^{17}$ Lihat Haryatmoko, Kekuasaan Melahirkan Anti-Kekuasaan, h. 4.

${ }^{18}$ Lihat Foucault, The History of Sexuality, Vol I: An Introduction, (New York, Vintage, 1978), h. 95

${ }^{19}$ Lihat Foucault, Discipline and Punish; the Birth of the Prison (Vintage Books, 1995), h. 194

${ }^{20}$ Foucault, Discipline and Punish; the Birth of the Prison, h. 12.

${ }^{21}$ Lihat Sunu Hardiyanta, Disiplin Tubuh; Bengkel Individu Modern (LKIS, 1997), h. 75.

${ }^{22}$ Discipline and Punish; the Birth of the Prison (Vintage Books, 1995), h. 27.

${ }^{23}$ Lihat Haryatmoko, Kekuasaan Melahirkan Anti-Kekuasaan, h. 5.

${ }^{24}$ Haryatmoko, Kekuasaan Melahirkan Anti-Kekuasaan, h. 9.

${ }^{25}$ Nusantaraislam.blogspot.com. Menengok Perkampungan Jamaah An-Nadzir di Sulsel. Diakses tanggal 6 Juni 2012

${ }^{26}$ Wawancara dengan Arif dan Umar (keduanya merupakan anggota Jamaah an-Nadzir)

${ }^{27}$ Senjata tajam khas Sulawesi Selatan

${ }^{28}$ Wawancara dengan arif

${ }^{29}$ Wawancara dengan umar (anggota jamaah an-nadzir)

${ }^{30}$ Wawancara dengan arif (anggota jamaah an-nadzir)

${ }^{31}$ Wawancara dengan ustad Rangka

${ }^{32}$ Lihat Sachedina, Islamic Messianism The Idea of Mahdi in Twelver Shi'ism (State University of New York Press: Albany, 1981), h. 2. h. 3 .

${ }^{33}$ Lihat Ibrahim Amini, Imam Mahdi: Penerus Kepemimpinan Ilahi (Islamic center, 2002),

${ }^{34}$ Lihat Sartono, Pemberontakan Petani Banten Tahun 1888 dalam buku Islam di Asia Tenggara; Perpektif Sejarah (LP3ES, 1989), h. 217.

${ }^{35}$ Lihat Sartono, Ratu Adil, Sinar Harapan, 1984, h. 16

${ }^{36}$ Sartono, Ratu Adil, Sinar Harapan, h. 21-22

${ }^{37}$ Wawancara dengan ustad Rangka

${ }^{38}$ Wawancara dengan ustad Rangka

${ }^{39}$ Wawancara dengan Arif

${ }^{40}$ Wawancara dengan Arif 
2009), h. 13.

${ }^{41}$ Lihat Usman, Tragedi Patriot Pemberontakan Kahar Muzakkar (Yogyakarta: Narasi,

${ }^{42}$ Usman, Tragedi Patriot Pemberontakan Kahar Muzakkar, h. 13

${ }^{43}$ Usman, Tragedi Patriot Pemberontakan Kahar Muzakkar, h. 92.

${ }^{44}$ Usman, Tragedi Patriot Pemberontakan Kahar Muzakkar, h. 93.

${ }^{45}$ Banyak bangsawan yang terlibat aktif menjadi gerilyawan semasa pendudukan Jepang dan Belanda. Mereka juga sangat menderita pada masa-masa tersebut. Setelah kemerdekaan, mereka berharap dapat direkrut menjadi anggota TNI, namun seperti banyak gerilyawan lainnya di Sulawesi Selatan, sangat sedikit dari mereka yang mempunyai latar belakan pendidikan Barat yang dijadikan standar utama pemerintah dalam rekrutmen tentara nasional.

${ }^{46}$ Lihat Sillars Harvey, Pemberontakan Kahar Muzakkar; Dari Tradisi ke DI/TII (Jakarta: Pustaka Utama Grafiti, 1989), h. 200.

${ }^{47}$ Sillars Harvey, Pemberontakan Kahar Muzakkar;... h. 333.

${ }^{48}$ Lihat Taufan, Tinjauan Sosiologi Hukum Jamaah An-nadzir, h. 145.

${ }^{49}$ Taufan, Tinjauan Sosiologi Hukum Jamaah An-nadzir, h. 147.

${ }^{50}$ Istilah yang digunakan Jamaah an-Nadzir untuk memistifikasi sosok Pemuda Bani Tamim yang mereka yakini

${ }^{51}$ Wawancara dengan Arif (anggota Jamaah an-Nadzir)

${ }^{52}$ Wawancara dengan Rangka.

${ }^{53}$ Wawncara dengan arif.

${ }^{54}$ Lihat Gibson, Narasi Islam dan Otoritas di Asia Tenggara. h. 86-90.

${ }^{55}$ Wawancara dengan Rangka

${ }^{56}$ Wawancara dengan Kepala Seksi Penerangan Dan Penyuluhan Agama Masyarakat Kementerian Agama Kabupaten Gowa.

${ }^{57}$ Untuk penjelasan lebih lanjut tentang pembagian stratifikasi soasial masyarakat Makassar lihat Hamid Abdullah, Manusia Bugis Makassar (Jakarta: Inti Idayu Press, 1985), h. 111.

${ }^{58}$ Lihat Pelras, Manusia Bugis (Jakarta: Nalar, 2006), h. 196.

${ }^{59}$ Telah umum dan mapan diketahui bahwa kedua tokoh (Syekh Yusuf dan Kahar Muzakkar) Sulawesi Selatan tersebut dimistifikasi dan dianggap keramat oleh banyak masyarakat Sulawesi Selatan, baik semasa hidupnya terlebih setelah kematian mereka.

${ }^{60}$ Lihat Michel Foucault, The History of Sexsuality, Vol I: An Introduction (New York, Vintage, 1978) h. 95. 


\section{Daftar Pustaka}

Abdullah, Hamid. Manusia Bugis Makassar, Jakarta. Inti Idayu Press. 1985.

Amini, Ibrahim. Imam Mahdi: Penerus Kepemimpinan Ilahi, Jakarta. Islamic Center. 2002.

Berger, Peter (ed). Kebangkitan Agama Menantang Politik Dunia. Yogyakarta. Penerbit Ar-Ruzz. 2003.

Bertens, K. Filsafat Barat Perancis. Jakarta. Gramedia Pustaka Utama, 2001.

Deal, William E, and Beal, Timothy K. Theory for Religious Studies, New York. Routledge, 2005.

Foucault, Michel. The History of Sexuality, Vol I: An Introduction. New York. Vintage, 1978.

Foucault, Michel. Discipline and Punish; the Birth of the Prison, New York. Vintage Books, 1995.

Gibson, Thomas. Narasi Islam dan Otoritas di Asia Tenggara, Makassar. Penerbit Ininnawa, 2012.

Hardiyanta, Sunu. Disiplin Tubuh; Bengkel Individu Modern, Yogyakarta. LKiS, 1997.

Haryatmoko. Dominasi Penuh Muslihat: Akar Kekerasan dan Diskriminasi'. Jakarta, Gramedia, 2010.

Haryatmoko, Kekuasaan Melahirkan Anti-Kekuasaan, Majalah Basis.

Harvey, Sillars. Pemberontakan Kahar Muzakkar; Dari Tradisi ke DI/TII, Jakarta: Pustaka Utama Grafiti, 1989.

Hobsbawm, Eric \& Ranger, Terence (Eds). The Invention Of Tradition, Cambridge, Great Britain: Cambridge University Press, 2000.

Ibrahim, Ahmad dkk. Islam di Asia Tenggara; Perspektif Sejarah. Jakarta: LP3ES, 1989.

Kartodirdjo, Sartono. Ratu Adil. Jakarta: Sinar Harapan, 1984.

Kartodirdjo, Sartono. Catatan Tentang Segi-Segi Messianistis Dalam Sejarah Indonesia'. Yogyakarta: Penerbit Universitas Gadjah Mada, 1959.

Kartodirdjo, Sartono. Catatan Tentang Segi-Segi Messianistis Dalam Sejarah Indonesia'. Yogyakarta: Penerbit Universitas Gadjah Mada, 1959.

Mattulada. LATOA: Satu Lukisan Analitis terhadap Antropolgi Politik Orang Bugis'. Makassar: Hasanuddin University Press, 1995. 
Nusantaraislam.blogspot.com. Menengok Perkampungan Jamaah An-Nadzir di Sulsel. Diakses tanggal 6 Juni 2012

Pelras, Christian. Manusia Bugis, Jakarta: Nalar, 2006.

Sachedina, Abdulazis. Islamic Messianism The Idea of Mahdi in Twelver Shi'ism. Albany. State University of New York Press, 1981.

Sunardi, Teori Wacana dalam The History of Sexsuality. Hand out Mata Kuliah, tidak diterbitkan.

Taufan, Muhammad. Tinjauan Sosiologi Hukum Jamaah An-Nadzir. Makassar. Universitas Islam Negeri Alauddin, 2012.

Usman. Tragedi Patriot Pemberontakan Kahar Muzakkar, Yogyakarta: Narasi, 2009. 